\title{
UJI SOMATIK INKOMPATIBILITAS Ganoderma steyaertanum YANG MENYERANG KEBUN BENIH Acacia mangium Willd. DI WONOGIRI, JAWA TENGAH
}

\author{
Somatic Incompatibility Test Ganoderma steyaertanum which Attack Seed Orchad of Acacia \\ mangium at Wonogiri, Central Java
}

\section{Nur Hidayati ${ }^{1}$ dan/and Siti Husna Nurrohmah ${ }^{2}$}

Balai Besar Penelitian Bioteknologi dan Pemuliaan Tanaman Hutan, Jl Palagan Tentara Pelajar km 15

Purwobinangun, Pakem, Sleman, Yogyakarta, Indonesia

Email: inunghidayati@yahoo.com ${ }^{1)}$; siti_husna_n@yahoo.com ${ }^{2)}$

Tanggal diterima: 28 Maret 2014; Tanggal direvisi: 10 Juli 2015; Tanggal disetujui: 11 Agustus 2015

\begin{abstract}
Ganoderma steyaertanum is a pathogen which causing root rot disease to Acacia mangium. This study aimed to the genetic diversity of G. steyaertanum, A. mangium at Wonogiri, Central Java. Using somatic incompatibility. Genetic material consisted of isolates G. steyaertanum, collected from seed orchad. Each isolate with other and repeated 3 times. Observations were conducted on fungal morphology characterization and scoring calculation using modified Latifah-Ho method. Self pairing test showed compatible reactions. Otherwise incompatible reactions occured when different isolates were paired. Eight isolates of G. steyaertanum were different clone and not identic. Incompatible reaction was indicated by the formation of inhibition zone, barrage formation and pigmentation.
\end{abstract}

Keywords: Acacia mangium, Ganoderma steyaertanum, root rot, somatic incompatibility

\begin{abstract}
ABSTRAK
Ganoderma steyaertanum merupakan penyebab penyakit busuk akar yang menyerang Acacia mangium. Tujuan dari penelitian ini untuk melihat keragaman genetik G. steyaertanum menggunakan uji somatik inkompatibilitas Kebun Benih A. mangium F1 di Wonogiri, Jawa Tengah. Materi genetik berupa 8 isolat $G$. steyaertanum yang diperoleh dari Kebun Benih A. mangium F1 di Wonogiri, Jawa Tengah. Setiap isolat dipasangkan dengan isolat lainnya dan diulang 3 kali. Penelitian dilakukan dengan mengamati morfologi jamur dan skoring menggunakan metode Latifah-Ho yang telah dimodifikasi. Hasil uji somatik inkompatibilitas menunjukkan bahwa semua pasangan isolat dengan sesamanya (self-pairing) memberikan reaksi kompatibel, sedangkan isolat yang berpasangan dengan bukan dirinya menunjukkan reaksi inkompatibel. G. steyaertanum yang menyerang kebun benih A. mangium F1 di Wonogiri memiliki keragaman genetik yang tinggi dan tidak berasal dari klon yang sama dan identik. Reaksi inkompatibel ditunjukkan dengan pembentukan zona jarang, zona bendungan dan pigmentasi berwarna cokelat oranye kemerahan.
\end{abstract}

Kata kunci: Acacia mangium, busuk akar, Ganoderma steyaertanum, somatik inkompatibilitas

\section{PENDAHULUAN}

Hutan Tanaman Industri (HTI) merupakan usaha membangun hutan tanaman untuk meningkatkan produktivitas hutan produksi, optimalisasi pemanfaatan ruang kelola dan menunjukkan daya saing produksi hasil hutan tanaman dengan menerapkan silvikultur sesuai dengan tapaknya (satu atau lebih sistem silvikultur) dalam rangka memenuhi kebutuhan bahan baku industri hasil hutan kayu maupun non kayu (Dephut, 2009). Jenis yang ditanam untuk pembangunan HTI adalah jenis-jenis tanaman cepat tumbuh seperti Acacia mangium Willd. (mangium), Eucalyptus spp., Gmelina arborea Roxb. dan Paraserianthes falcataria L. (Nielsen). Pertanaman mangium di Sumatera dan Kaliman-tan telah mengalami kerugian akibat dari penya-kit busuk akar yang disebabkan oleh Ganoderma philippii (Bres. \& Henn.exSacc). Dua kebun benih di Wonogiri, Jawa Tengah yang ditanami dari genus Acacia yang berbeda yaitu Acacia mangium dan Acacia auriculiformis mengalami serangan busuk akar yang disebabkan oleh Ganoderma steyaertanum 
(B) Sm \& Sivasith (Glen et al., 2009). Penyakit busuk akar di kebun benih mangium tersebut telah menimbulkan ke-matian $6,8 \%$ pada tahun 2003 dan meningkat menjadi $40 \%$ pada bulan Januari 2013 (Hidayati, 2013).

Gejala serangan penyakit busuk akar tingkat ringan pada tanaman secara umum adalah layu, tidak berkembang, kehilangan helai daun sampai lodoh pada batang. Pada serangan tingkat lanjut, secara umum penyakit dapat diidentifikasi dengan kemunculan tubuh buah. Tubuh buah ini keras dan berkayu dengan ukuran yang cukup besar. Ukuran tubuh buah dapat mencapai diameter $15 \mathrm{~cm}$ dan ketebalan $5 \mathrm{~cm}$. Warna tubuh buah dari cokelat muda hingga cokelat tua dan bahkan jingga. Bagian atas tubuh buah dapat agak mengkilat dengan bagian bawah berwarna putih (Henessy \& Daly, 2007).

Serangan jamur Ganoderma pada akar pohon di lapangan sulit dideteksi karena berada di dalam tanah. Akar yang baru terinfeksi tertutup oleh rhizomorfa berwarna merah dan miselium berwarna putih. Secara umum gejala pada bagian pohon di permukaan tanah adalah adanya penurunan vigor yang cepat yang ditandai dengan perubahan warna, daun layu, menguning, menggugurkan daun dan akhirnya tanaman mati. Tubuh buah jamur kadang terbentuk di bagian bawah batang yang sudah mati, yang berbatasan dengan permukaan tanah (Herliana et al., 2012). Pengendalian penyakit busuk akar oleh jamur $G$. steyaertanum pada tanaman mangium, terlebih dahulu perlu diketahui pola sebarannya. Pola sebaran ini dapat diketahui dengan melakukan uji somatik inkompatibilitas, kemudian dari uji soma-tik inkompatibitas akan diperoleh informasi apakah setiap pohon yang terserang jamur tersebut berasal dari klon jamur yang sama atau berbeda. Hasil uji somatik inkompatibilitas ini nantinya dapat digunakan untuk menganalisis populasi dan penyebaran jamur di lapangan (Fries, 1987).
Penelitian ini bertujuan untuk menguji somatik inkompatibilitas terhadap serangan jamur $G$. steyaertanum penyebab penyakit busuk akar pada tanaman mangium yang menyerang kebun benih mangium generasi pertama di Wonogiri, Jawa Tengah. Tes somatik inkompatibilitas merupakan salah satu cara untuk memahami pola penyebaran penyakit agar dapat dikembangkan cara-cara untuk mencegah meluasnya serangan penyakit.

\section{METODE PENELITIAN}

\section{A. Isolat Jamur G. steyaertanum}

Isolat jamur G. steyaertanum berasal dari isolasi tubuh buah jamur yang tumbuh pada pangkal batang tanaman mangium dengan nomor pohon yang berbeda-beda di kebun benih mangium generasi pertama, Wonogiri, Jawa Tengah. Identifikasi jenis jamur dilakukan secara morfologi terhadap isolat hasil isolasi tubuh buah jamur. Isolat ditumbuhkan pada media PDA (Potato Dekstrose Agar) dengan konsentrasi 23,4 $\mathrm{gr} / 600 \mathrm{ml}$ aquades. Ada 8 isolat jamur Ganoderma yang digunakan dalam penelitian ini. Delapan isolat tersebut adalah 8-1-115 (A), 161-34 (B), 11-14-116 (C), 11-15-102 (D), 42-2-16 (E), 36-11-58 (F), 41-13-52 (G), 12-19-38 (H).

Isolat jamur Ganoderma yang digunakan untuk tes somatik inkompatibilitas disubkultur dari koleksi kultur yang disimpan dalam media yang berbentuk agar miring ke dalam petridish (initial plate). Tujuan pembuatan initial plate ini agar isolat jamur mempunyai umur yang seragam dan pertumbuhan yang seragam dalam hal meristematis, viabilitas dan vigoritas. Pengambilan dilakukan secara acak, ada yang berasal dari pohon yang terletak berdekatan serta ada yang berasal dari pohon yang terletak berjauhan. Berikut letak pohon mangium di mana tubuh buah $G$. steyaertanum diambil untuk uji somatik inkompatibilitas dalam peta kebun benih mangium F-1 Wonogiri, Jawa Tengah. 


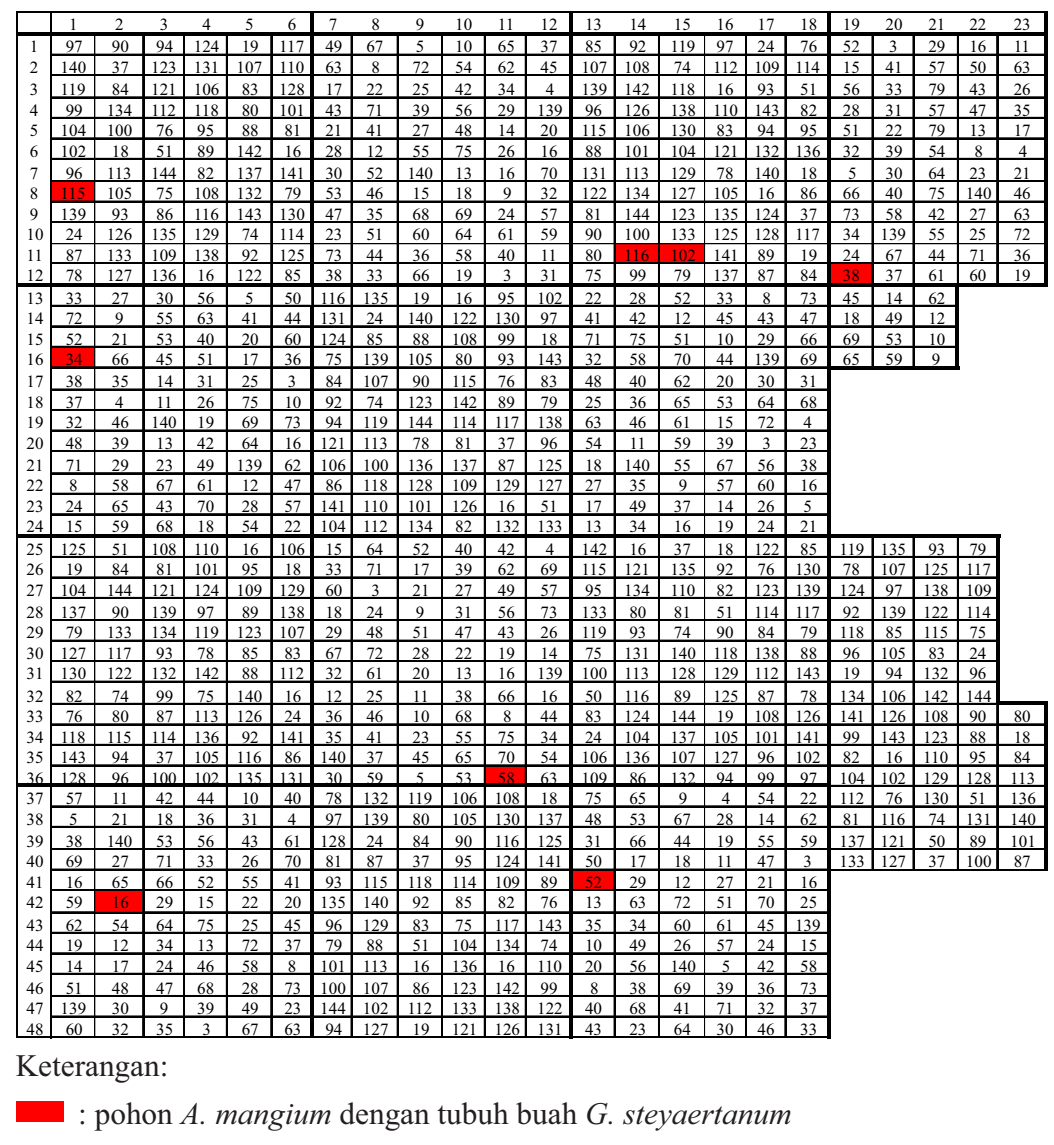

Sumber (Source): Diolah dari data lapang (Compiled and analyzed from field data)

Gambar(Figure) 1. Diagram sebaran tubuh buah G. steyaertanum pada kebun benih A. mangium F-1 di Wonogiri, Jawa Tengah (Diagram of the spread of G. steyaertanum fruit bodies on the seed orchad of A. mangium F-1 in Wonogiri, Central Java) 

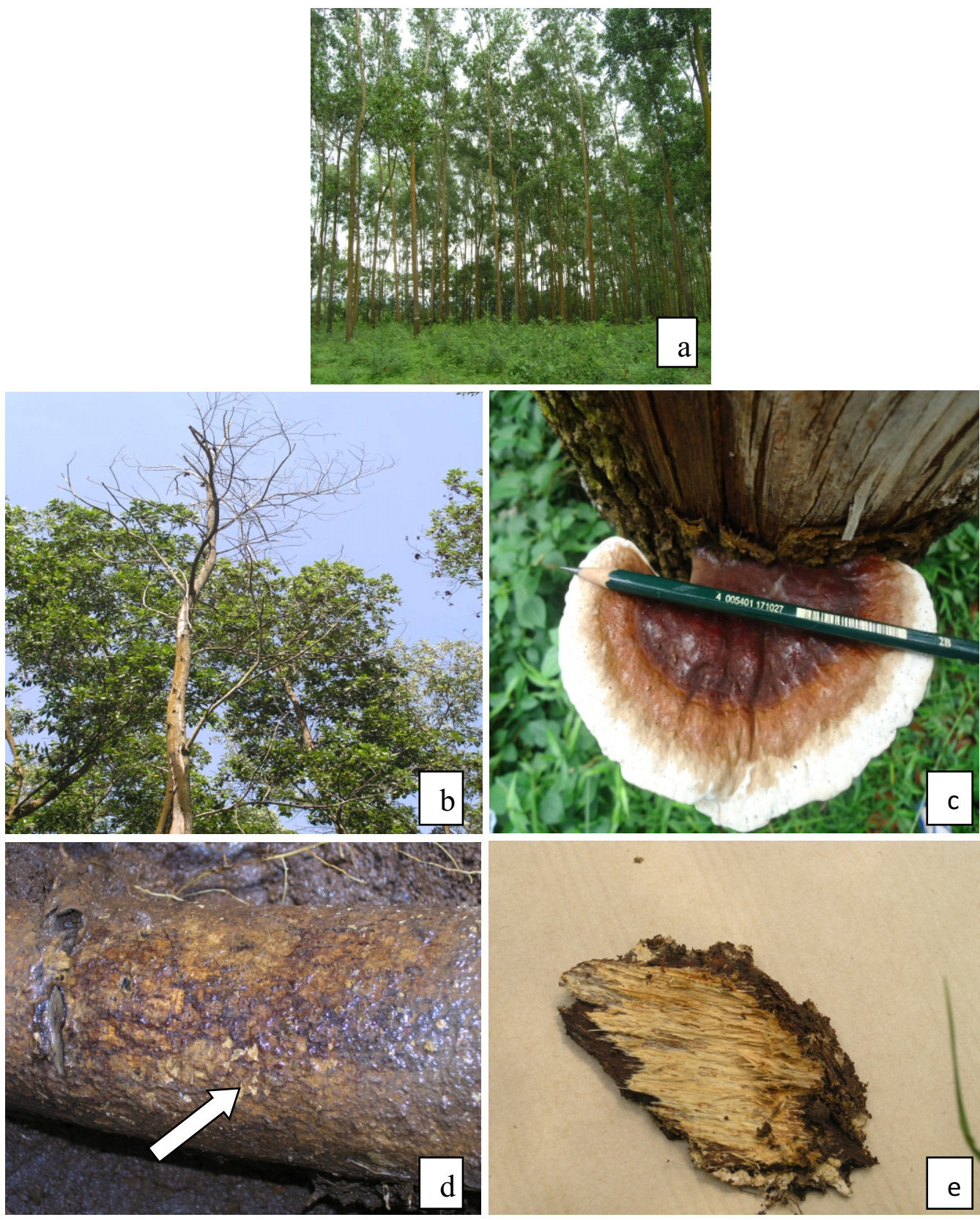

Sumber (Source)

???

Gambar(Figure) 2. a. Kebun benih A. mangium generasi pertama di Wonogiri, Jawa Tengah, b. Tanaman $A$. mangium yang mati karena penyakit busuk akar; c. Tubuh buah jamur G. steyaertanum penyebab penyakit busuk akar merah; d. Akar A. mangium yang terserang G. steyaertanum, e. Miselium G. steyaertanum pada bagian akar sebelah dalam (a. The first generation seed orchad of mangium in Wonogiri, Central Java; b. A. mangium that died caused by root rot; $c$. Fruit body of G. steyaertanum causing root rot disease; $d$. Root of A. mangium infected of $\mathrm{G}$. steyaertanum, e. Micelium of G. steyaertanum inside of mangium's root). 


\section{A. Pengujian Somatik Inkompatibilitas ja- mur G. steyaertanum}

Pengujian somatik inkompatibilitas dilakukan untuk mengetahui model penyebaran jamur G. Steyaertanum dalam suatu lokasi, selain itu dapat juga digunakan untuk mengetahui keragaman genetik dari satu jenis jamur G. steyaertanum. Prosedur pengujian untuk test somatik inkompatibilitas menurut Latifa \& Ho, 2005 yaitu:

1. Dua isolat jamur G. steyaertanum dipasangkan pada media PDA dalam cawan petri (berdiamater $9 \mathrm{~cm}$ ).

2. Blok inokulum diambil dari initial plate dengan ukuran $3 \mathrm{~mm}^{2}$, diletakkan dengan jarak \pm 1-2 $\mathrm{mm}$ antar dua isolat (berdekatan tetapi tidak bersentuhan). Pembuatan blok inokulum diusahakan mempunyai ukuran yang sama antara yang satu dengan yang lainnya dalam setiap cawan petri, agar mempunyai pertumbuhan yang seragam.

3. Isolat induk (parents culture) dibuat dari initial plate untuk setiap isolat yang akan diuji, tujuannya sebagai referensi isolat dalam memberi skor uji pasangan.

4. Masing-masing kombinasi isolat yang diuji dan isolat induk dibuat dalam 3 ulangan.

5. Kultur jamur diinkubasi pada suhu $25^{\circ} \mathrm{C}$ dalam ruang inkubasi.

6. Ada atau tidaknya kontaminasi diamati dan diukur luas pertumbuhan dengan milimeter blok setiap 2 hari sekali hingga mencapai penuh (memenuhi cawan petri) atau konstan.

7) Hasil uji pasangan dievaluasi setelah 5 hari ditanam dengan menilai reaksi inkompatibilitas antar isolat berdasarkan tingkat pertentangannya dengan menggunakan metode Adaskaveg \& Gilbertson (1987) dalam Latifah dan Ho (2005) yang telah dimodifikasi. Luas masingmasing jamur diukur dengan mengunakan milimeter blok setiap 2 hari sekali hingga mencapai penuh (memenuhi cawan petri) atau konstan.

\section{B. Analisis Data}

Data yang diperoleh berupa foto-foto dianalisis secara deskriptif, sedangkan data luas diukur menggunakan kertas millimeter blok dan hasilnya dikonversi ke dalam satuan $\mathrm{mm}^{2}$.

\section{HASIL DAN PEMBAHASAN}

\section{A. Data Skoring Uji Somatik Inkompatibili- tas Jamur G. steyaertanum}

Hasil dari uji pasangan dua isolat jamur G. steyaertanum baik secara self-pairing atau dengan isolat yang berbeda pohon menunjukkan reaksi yang berbeda untuk setiap lokasi. Reaksi pemasangan antar dua isolat jamur G. steyaertanum dapat dilihat pada Tabel 1 .

Tabel (Table) 1. Uji somatik inkompatibilitas antar isolat jamur G. steyaertanum (Somatic incompatibility test beetwen isolates of G. steyaertanum)

\begin{tabular}{|c|c|c|c|c|c|c|c|c|}
\hline $\begin{array}{c}\text { Isolat jamur uji } \\
\text { (G. steyaertanum test isolate) }\end{array}$ & A & B & $\mathrm{C}$ & $\mathrm{D}$ & $\mathrm{E}$ & $\mathrm{F}$ & G & $\mathrm{H}$ \\
\hline $\mathrm{A}$ & 0 & 2 & 1 & 2 & 1 & 1 & 2 & 2 \\
\hline B & & 0 & 2 & 1 & 2 & 2 & 2 & 2 \\
\hline $\mathrm{C}$ & & & 0 & 2 & 1 & 1 & 1 & 2 \\
\hline $\mathrm{D}$ & & & & 0 & 2 & 1 & 2 & 2 \\
\hline $\mathrm{E}$ & & & & & 0 & 1 & 2 & 2 \\
\hline $\mathrm{F}$ & & & & & & 0 & 1 & 1 \\
\hline G & & & & & & & 0 & 2 \\
\hline $\mathrm{H}$ & & & & & & & & 0 \\
\hline
\end{tabular}

Sumber (Source): Diolah dari data lapang (Compiled and analyzed from field data)

Keterangan (Remarks):

0 : kompatibel yaitu tidak terjadi reaksi (Compatible means that there is no reaction)

1 : inkompatibel yaitu terjadi reaksi dengan tanpa pigmentasi (Incompatible means there is reaction without pigmentation)

2 : inkompatibel yaitu terjadi reaksi dengan pembentukan pigmentasi di antara pertemuan dua miselium jamur (Incompatible means there is reaction with pigmentation occuring between two myceliums) 
Tabel 1 menunjukkan adanya nilai derajat pertentangan antar isolat. Reaksi yang ditunjukkan dalam uji somatik inkompatibilitas antara lain pembentukan zona jarang antar miselium jamur yang dipasangkan dan dinding pemisah yang merupakan dinding sclerotia dari penggumpalan hifa yang terbentuk pada pertemuan dua miselium jamur. Semua pasangan isolat selain isolat self-pairing menunjukkan reaksi yang inkompatibel yang berarti terdapat keragaman genetik, geno-tipnya berbeda dan tidak berasal dari satu klon yang sama meskipun mempunyai kesamaan secara morfologi.

Berdasarkan hasil pengamatan blok inokulum jamur G. steyaertanum yang telah ditanam, tumbuh membentuk miselium berupa serabut halus berwarna putih dengan ciri khas warna kuning pada bagian tengah kultur yang terbentuk sejak awal pertumbuhan dan terus ada sampai kultur berwarna cokelat tua. Miselium cenderung datar, tidak menggumpal dan halus pada permukaannya. Pada pertumbuhan lanjut, miselium berwarna kuning-cokelat muda-cokelat tua yang menyebar secara radial, sedangkan bagian tengahnya tetap berwarna kuning. Permukaannya halus dan datar, bentuk miseliumnya cenderung menempel pada permukaan media. Terkadang tampak adanya hifa yang mengeras pada bagian tengah yang menyebar keluar yang biasa disebut sebagai crustose, ada juga yang membentuk gumpalan miselium pada permukaannya.
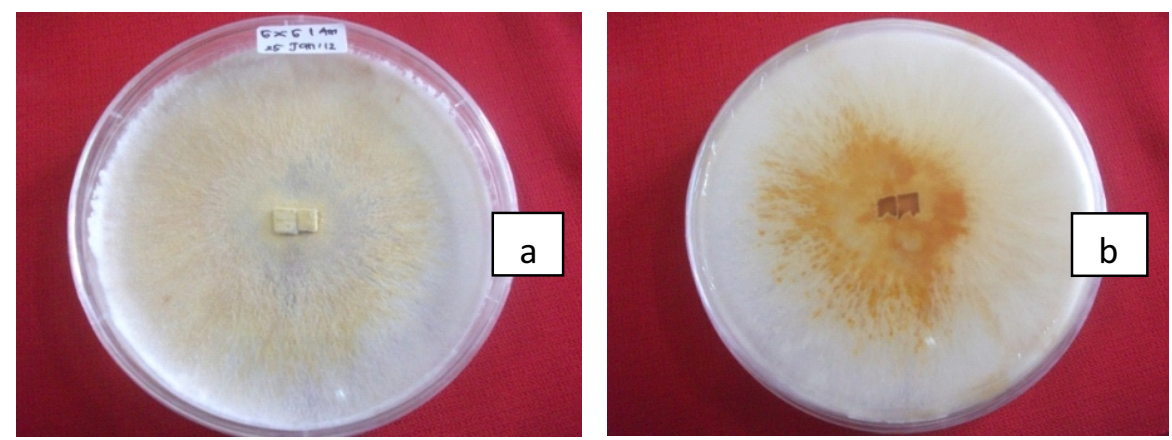

Sumber (Source):
Reaksi kompatibel atau tidak adanya keragaman genetik ditemukan pada uji pasangan secara self-pairing (A-A, B-B, C-C, D-D, E-E, F-F, G$\mathrm{G}, \mathrm{H}-\mathrm{H})$. Pemasangan isolat jamur G. steyaertanum tidak membentuk garis pemisah di antara kedua miselium. Semua isolat tumbuh bersama dan menyatu dengan isolat yang lain membentuk koloni tunggal seperti pada Gambar 3 antara pasangan isolat $\mathrm{C}$. Hal tersebut sangat wajar karena isolat yang dipasangkan merupakan pasangan dengan dirinya sendiri yaitu pasangan isolat berasal dari kultur initial plate yang sama, yang berarti berasal dari klon yang sama jadi tidak akan menunjukkan reaksi inkompatibel dan akan menyatu membentuk koloni tunggal. Menurut Worall (2010), terbentuknya koloni tunggal terse-but terjadi karena miselia jamur saling bergabung dan hifa mengalami anastomosis yaitu penggabungan dua hifa yang berbeda menjadi hifa dikaryotik yang diikuti dengan perpindahan isi hifa. Anastomosis pada hifa biasanya diikuti dengan terbentuknya struktur septal khusus pada miselia jamur yang disebut dengan clamp connection yang merupakan ciri khas pada golongan Basidiomycetes.

Untuk luas jamur pada pasangan self-pairing tidak mempengaruhi antar pasangan isolat. Masing-masing jamur tidak saling menghambat pertumbuhan dan saling menyatu antar pertemuan kedua miselium (Gambar 4). Hal tersebut terjadi karena kedua isolat jamur berasal dari klon yang sama. Terlihat miselium dari kedua isolat saling menyatu.

Gambar(Figure)3. Koloni tunggal yang terbentuk pada reaksi kompatibel pada pasangan self-pairing ((a) tampak atas dan (b) tampak bawah) (Single colony formed by the compatible reaction on selfpairing (arrow sign (a) top view and (b) bottom view) 

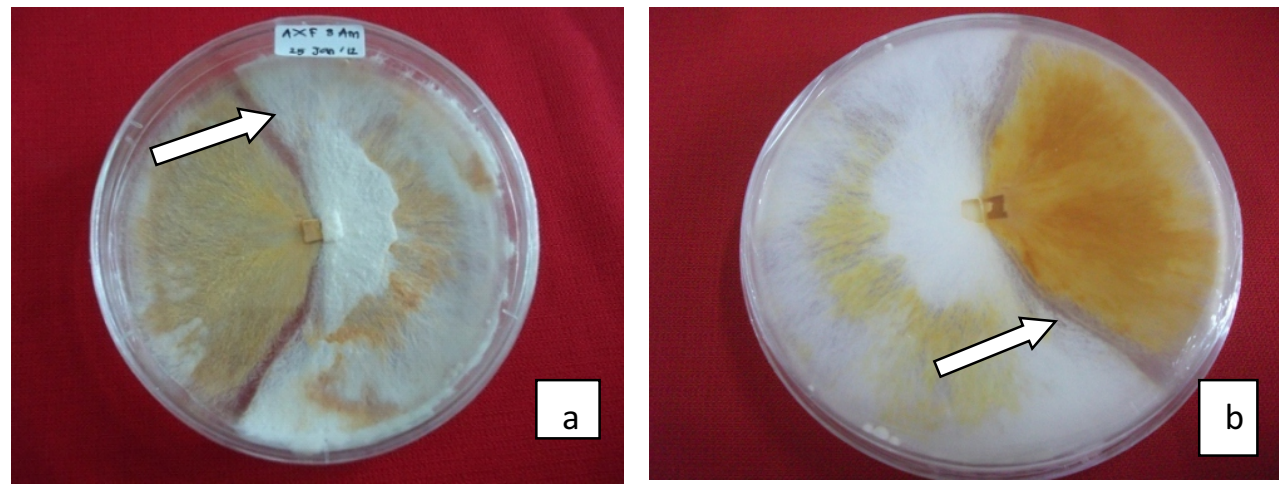

Sumber (Source):

???

Gambar(Figure) 4. Zona jarang antar miselium pada reaksi yang inkompatibel (tanda panah (a) tampak atas dan (b) tampak bawah) (Rare zone between myceliums in the incompatible reaction (arrow sign (a) top view and (b) bottom view)

Reaksi inkompatibilitas (reaksi ketidakcocokan somatik) ditemukan pada beberapa uji pasangan isolat. Reaksi ditunjukkan dalam berbagai macam fenomena bentuk demarkasi, mulai dari fenomena pembentukan zona jarang antar miselium jamur yang dipasangkan (Gambar 4), pembentukan garis demarkasi yang disertai pembentukan pigmentasi. Bentuk garis demarkasi terbentuk pada hampir semua pasangan isolat yang mempunyai tipe miselia yang berbeda atau tidak identik secara genetik baik pada monosporous atau miselia sekunder (Worall, 1997).

Luas pertumbuhan masing-masing isolat jamur ketika dipasangkan dengan isolat yang berbeda pohon menunjukkan hasil yang tidak berbeda jauh. Sebagai contoh adalah isolat A dan F yang pertumbuhannya cepat (Tabel 2) ketika kedua isolat dipasangkan perbedaan luasnya tidak terlalu jauh meskipun di tengah-tengah pertemuan miselium kedua isolat terdapat seperti garis pembatas yang merupakan reaksi inkompatibel, sehingga pertumbuhan hifa-hifa jamur akan kesamping (Gambar 4b). Dapat dilihat pada
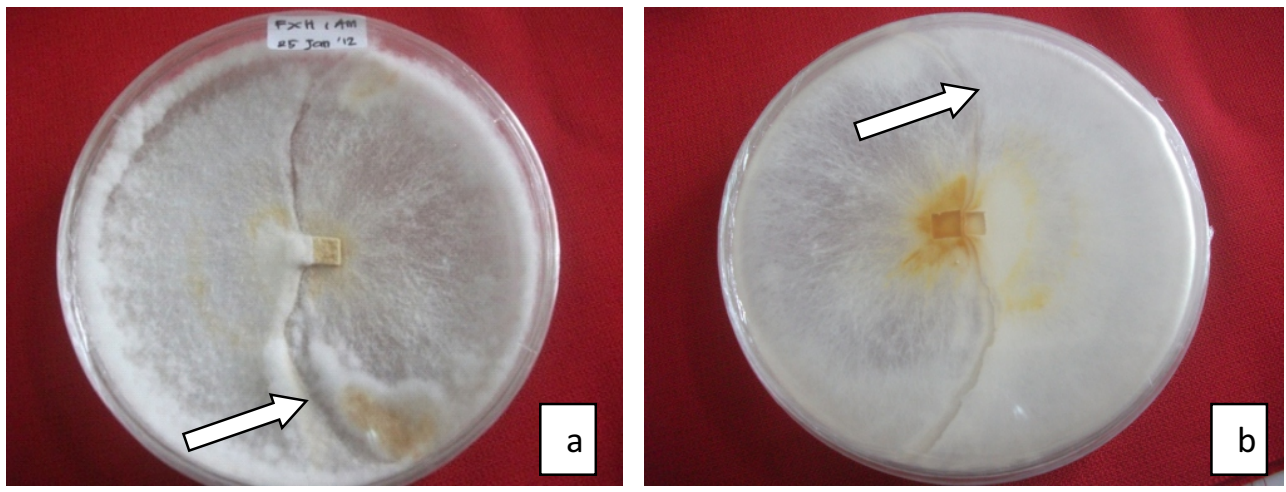

Sumber (Source):
Tabel 2 luas isolat parental jamur G. steyaertanum bahwa isolat jamur $\mathrm{F}$ sedikit lebih cepat daripada isolat jamur A sehingga pada Gambar 3b dapat terlihat juga bahwa luas jamur $\mathrm{F}$ sedikit lebih luas dari jamur A.

Reaksi ini kadang juga disertai dengan adanya pembentukan pigmentasi pada pertemuan miselium. Guler (2008) menjelaskan bahwa pembentukan pigmen di antara miselium jamur yang dipasangkan pada uji inkompatibilitas itu merupakan hal yang penting. Terbentuknya pigmentasi sangat membantu dalam menentukan inkompatibilitas suatu uji pasangan. Akan tetapi tidak semua reaksi inkompatibel membentuk pigmentasi pada pertemuan miseliumnya, seperti hasil yang dipaparkan oleh Suwandi et al., (2004) pada Rigidoporus lignosus menunjukkan dua tipe inkompatibilitas, yaitu adanya zona demarkasi miselium yang jarang tanpa adanya pigmentasi dan zona demarkasi miselium dengan pembentukan pigmentasi. Perbedaan pigmentasi ini dipengaruhi oleh faktor media kultur yang dapat mempengaruhi intensitas reaksi inkompatibili-tas.

Gambar(Figure) 5. Pembentukan zona bendungan berupa dinding sclerotia (tanda panah (a) tampak atas dan (b) tampak bawah) (The formation of the barrage zone occured in the form of sclerotia (arrow sign (a) top view and (b) bottom view) 
Hasil reaksi inkompatibilitas juga ditunjukkan dengan adanya dinding pemisah yang merupakan dinding sclerotia dari penggumpalan hifa yang terbentuk pada pertemuan dua miselium jamur. Seperti pada Gambar 5 yaitu antara pasangan isolat $\mathrm{F}$ dan isolat $\mathrm{H}$ yang ketika dipasangkan membentuk dinding sclerotia.

Hasil reaksi inkompatibilitas pada jamur Ganoderma menunjukkan adanya perbedaan pembentukan pigmentasi (Gambar 6). Sebelas reaksi inkompatibilitas uji pasangan A-C, A-E, A-F, B-D, C-E, C-F, C-G, D-F, E-F, F-G, F-H pada pertemuan miseliumnya tidak membentuk pigmentasi, dinding sclerotia maupun zona jarang. Kombinasi uji inkompatibilitas selain pasangan di atas dan selain self-pairing, membentuk pigmentasi pada pertemuan miseliumnya. Pigmentasi mulai dapat dilihat pada umur 6 hari yang ditandai dengan adanya garis berwarna kuning kecokelatan pada pertemuan miselium jamur yang berubah menjadi cokelat orange kemerahan pada umur lanjut seperti pada Gambar $6 \mathrm{~b}$ antara pasangan isolat $\mathrm{A}$ dan isolat $\mathrm{G}$. Pada perkembangan lanjut $G$. steyaertanum ini akan membentuk crustose yang bisa menyebab-kan kerancuan dalam melihat pigmentasi. Pigmentasi dari reaksi inkompatibilitas terlihat pada awal pertumbuhan miselium, berbeda halnya dengan crustose atau penggumpalan miselium yang akan terbentuk setelah isolat berumur tua (Puspitasari \& Rimbawanto, 2010). Pembentukan pigmentasi yang berwarna kuning dan zona bendungan juga terjadi pada uji somatik inkompatibilitas pada Trametes versicolor (L.) Lyod. (Guler \& Bicer, 2014).

\section{B. Pertumbuhan Isolat Parental Jamur $G$. steyaertanum}

Tabel 2 menunjukkan luas isolat parental jamur G. steyaertanum yang mencapai luas maksimum (memenuhi cawan petri) dengan waktu yang berbeda-beda.

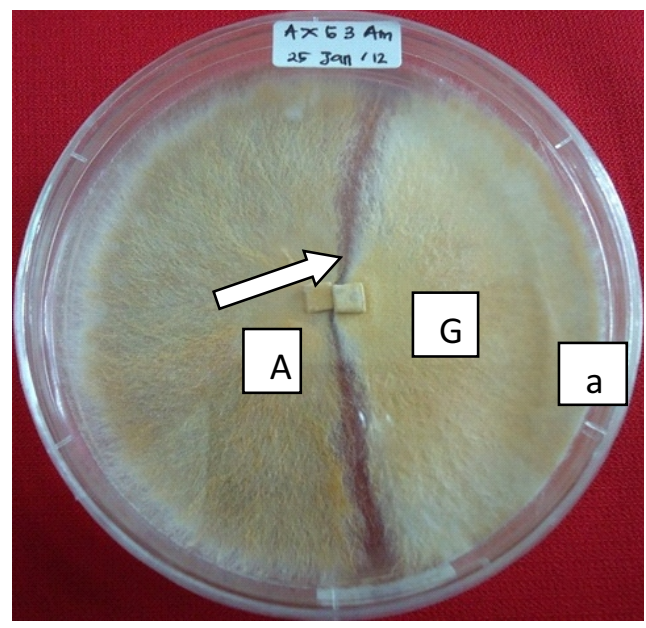

Sumber (Source):

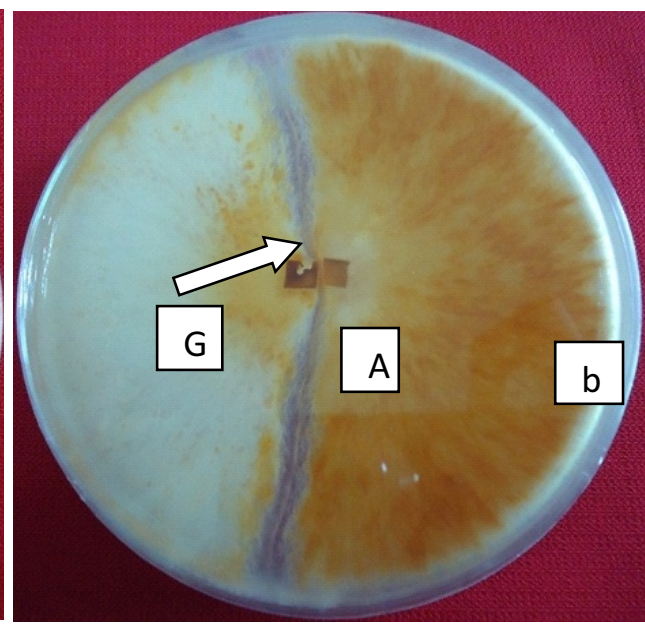

Gambar(Figure) 6. Pembentukan pigmentasi berwarna cokelat orange kemerahan (anak panah) pada zona garis demarkasi yang merupakan pertemuan antar dua isolat pada uji pasangan A-G. (a) tampak atas, (b) tampak bawah (The formation of orange-reddish brown pigmentation (arrow sign) on demarcation line zone which is the meeting point between two isolates in A-6 couple test (arrow sign (a) top view and (b) bottom view)) 
Tabel(Table)2. Luas pertumbuhan isolat parental jamur G. steyaertanum $\left(\mathrm{mm}^{2}\right)$ (Area of Fungal Growth of the Parental Isolates of G. steyaertanum $\left(\mathrm{mm}^{2}\right)$ )

\begin{tabular}{|c|c|c|c|c|c|c|c|c|c|c|}
\hline \multirow{2}{*}{$\begin{array}{c}\text { Isolat jamur } \\
\text { (Isolates of } \\
\text { G. steyaertanum) }\end{array}$} & \multicolumn{10}{|c|}{ Pengamatan hari ke- } \\
\hline & 5 & 7 & 9 & 11 & 13 & 15 & 17 & 19 & 21 & 23 \\
\hline isolat $\mathrm{A}$ & 710 & 1.200 & 2.625 & 4.550 & 5.400 & & & & & \\
\hline isolat B & 605 & 800 & 1.500 & 2.375 & 3.400 & 4.150 & 4.750 & 5.350 & 5.380 & \\
\hline isolat C & 500 & 575 & 1.675 & 2.850 & 3.975 & 5.400 & & & & \\
\hline isolat D & 540 & 675 & 1.075 & 1.525 & 2.325 & 2.900 & 3.425 & 4.000 & 4.350 & 4.450 \\
\hline isolat E & 375 & 525 & 925 & 1.800 & 3.375 & 4.200 & 5.400 & & & \\
\hline isolat $\mathrm{F}$ & 1.570 & 2.450 & 4.375 & 5.400 & & & & & & \\
\hline isolat $\mathrm{G}$ & 550 & 875 & 2.075 & 3.875 & 5.400 & & & & & \\
\hline isolat $\mathrm{H}$ & 1.440 & 2.125 & 3.800 & 5.400 & & & & & & \\
\hline
\end{tabular}

Sumber (Source): Diolah dari data lapang (Compiled and analyzed from field data)

Keterangan (Remarks): Luas maksimal $5400 \mathrm{~mm}^{2}$......

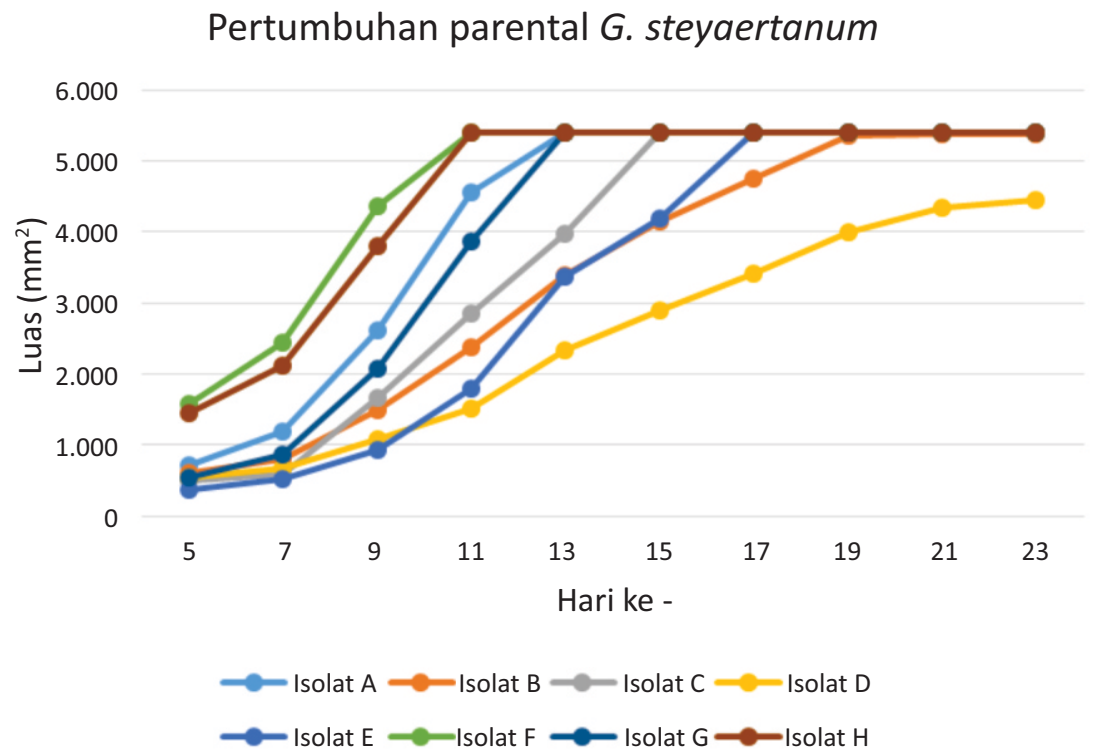

Sumber (Source): Diolah dari data lapang (Compiled and analyzed from field data)

Gambar(Figure) 7. Pertumbuhan isolate parental G. steyaertanum (Fungal growth of the parental isolates of $\mathrm{G}$. steyaertanum $\left(\mathrm{mm}^{2}\right)$ )

Pertumbuhan parental jamur G. Steyaertanum dapat dilihat adanya perbedaan pertumbuhan antar isolat jamur uji. Pengamatan dilakukan setiap 2 hari sekali pada waktu isolat berumur 5 hari. Masing-masing isolat jamur uji mempunyai pertumbuhan yang hampir sama dilihat dari pertambahan luas dari pengamatan pertama ke pengamatan kedua dan dari pengamatan kedua ke pengamatan ketiga. Semua isolat mempunyai kecenderungan laju pertumbuhan dari lambat kemudian menjadi cepat. Laju pertumbuhan jamur Ganoderma dapat dilihat pada Tabel 2. yang menunjukkan bahwa pertumbuhan pada masing-masing isolat jamur Ganoderma berbeda-beda. Beberapa isolat jamur ada yang pertumbuhannya cepat dan lambat, hal tersebut dapat dilihat dengan pertambahan luas setiap melakukan pengamatan dan waktu yang dibutuhkan oleh masing-masing isolat jamur untuk mencapai luas maksimum (Tabel 2). Seperti pada isolat jamur kode $\mathrm{F}, \mathrm{H}$ yang luasnya penuh pada pengamatan ke 4 dan isolat jamur A, G luasnya penuh pada pengamatan hari ke 13. Isolat yang pertumbuhannya lambat terjadi pada isolat jamur B dan D yang sampai 3 kali pengamatan luasnya konstan (tidak bertambah). Hal tersebut mem- 
buktikan bahwa karakteristik pertumbuhan dari masing-masing jamur tidak sama meskipun satu spesies.

Pertumbuhan jamur dipengaruhi oleh subtrat (nutrisi), $\mathrm{pH}$, suhu dan senyawa kimia yang dikeluarkan oleh jamur. Faktor-faktor yang mempengaruhi pertumbuhan jamur dalam penelitian dibuat homogen sehingga di duga faktor dari dalam isolat jamur sendiri yang menyebabkan adanya perbedaan pertumbuhan. Pertumbuhan merupakan pertambahan volume sel, karena adanya pertambahan protoplasma dan senyawa asam nukleat yang melibatkan sintesis DNA dan pembelahan mitosis. Pertambahan volume sel tersebut adalah irreversible, artinya tidak dapat kembali ke volume semula. Faktor internal yang mempengaruhi pertumbuhan dan perkembangan tumbuhan dapat dibedakan atas faktor intraseluler dan faktor interseluler. Faktor intraseluler adalah faktor dari dalam sel, berupa gen yang mempengaruhi sifat tumbuhan dan memberikan potensi bagi tumbuhan untuk tumbuh dan berkembang. Umumnya suatu miselium digunakan sebagai kriteria terjadinya pertumbuhan, karena masa sel-sel tersebut berada dari satu sel. Sesuatu yang semula tidak terlihat, yaitu spora atau konidia jamur atau spora fungi akan menjadi miselium atau yang dapat dilihat. Bila suatu konidia atau spora jamur ditanam di atas agar dalam cawan petri, maka setelah satu atau dua hari baru terlihat suatu permukaan agar yang dapat berupa tetesan kental apabila suatu khamir atau berupa benang-benang bila bentuk tersebut adalah kapang (Gandjar et al., 2006).
Hasil uji pasangan dan luas pertumbuhan isolat jamur G. steyaertanum ini dievaluasi setelah 1 minggu karena miselium pada jamur $G$. steyaertanum sudah mulai tumbuh dan bisa untuk dinilai serta dihitung luasnya. Penghitungan luas jamur dilakukan saat kultur uji jamur Ganoderma berumur 6 hari. Parental plate isolat $\mathrm{F}$ dan $\mathrm{H}$ mencapai luas penuh pada umur kultur 10 hari, parental plate isolat A dan $\mathrm{G}$, mencapai luas penuh pada umur kultur 12 hari, parental plate isolat $\mathrm{C}$ mencapai luas penuh pada umur kultur 14 hari, parental plate isolat E mencapai luas penuh pada umur kultur 16 hari, sedangkan parental plate isolate B dan D pada umur kultur 24 luasnya konstan sampai 3 kali pengamatan tetap konstan. Hal tersebut dapat terjadi karena beberapa faktor kemungkinan yaitu isolat jamur tersebut siklus hidupnya berbeda yaitu pertumbuhan yang lambat dan kemungkinan nutrisi dalam media sudah habis, sehingga jamur tersebut tidak mampu tumbuh lagi.

Gambar 8 menunjukkan pertumbuhan antara isolat-isolat jamur yang diuji. Pertumbuhan isolat jamur B dan E belum ada yang dominan pada awal pertumbuhannya dan salah satu menjadi lebih dominan pada hari selanjutnya. Hal ini disebabkan karena adanya kompetisi ruang dan makanan pada kedua jamur yang berinteraksi menyebabkan pertumbuhan salah satu jamur terdesak (Purwantisari, 2009).

Somatik inkompatibilitas sudah tersebar luas pada makrofungi. Pentingnya memahami prinsip dan teknik uji somatik inkompatibilitas jamur dapat diterapkan pada berbagai jenis jamur yang

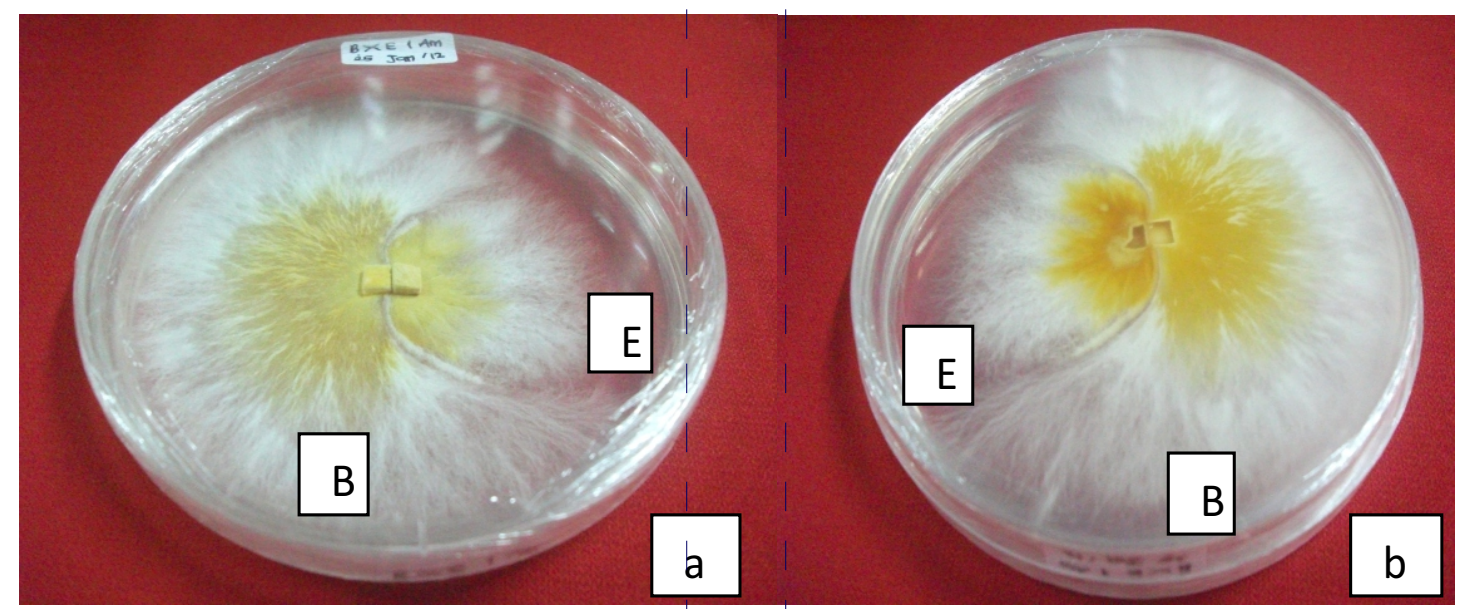

Sumber (Source): Diolah dari data lapang (Compiled and analyzed from field data)

Gambar (Figure) 8. Uji somatik inkompatibilitas antara isolat B X E (a) tampak atas (b) tampak bawah (Somatic incompatibility B XE isolate . (a) top view, (b) bottom view) 
menyebabkan penyakit pada tanaman. Evaluasi hasil uji pasangan setelah 2 minggu dengan menilai reaksi inkompatibilitas antar isolat berdasarkan tingkat pertentangannya dengan menggunakan metode Adaskaveg \& Gilbertson (1987) dalam Latifah \& Ho (2005) yang telah dimodifikasi. Somatik Inkompatibilitas digunakan untuk menunjukkan jika isolat jamur yang berasal dari genotip yang berbeda atau klon dari single genotipe. Somatik inkompatibilitas dalam Basidiomycetes adalah penolakan miselia yang berlainan genetik yang berfungsi untuk menjaga suatu individu tidak terjadi perubahan genetik. Somatik inkompatibilitas mengatur penolakan dan pengakuan alel-alel atau gen-gen yang sesuai dan tidak sesuai yang mengikuti pembentukan sel tubuh dalam sebuah grup organisme. Fries (1987) menjelaskan bahwa studi tentang somatik inkompatibilitas dapat digunakan untuk mengetahui apakah setiap pohon yang terserang jamur berasal dari klon jamur yang sama atau berbeda yang nantinya dapat digunakan untuk menganalisis populasi dan penyebaran jamur di lapangan. Studi tentang somatik inkompatibilitas ini dapat digunakan untuk mengetahui distribusi genotip pada suatu populasi (Puspitasari \& Rimbawanto, 2010).

\section{KESIMPULAN DAN SARAN}

\section{A. Kesimpulan}

Isolat-isolat $G$. steyaertanum pada mangium yang menunjukkan adanya somatik inkompatibilitas terjadi pada seluruh pasangan uji yang berbeda dengan terbentuknya zona jarang, dinding sclerotia tanpa pigmentasi maupun dinding sclerotia dengan pigmentasi.

\section{B. Saran}

Hasil uji somatik inkompatibilitas G. steyaertanum dari kebun benih mangium, Wonogiri, Jawa Tengah, menunjukkan reaksi inkompatibel antara dua isolat yang berbeda. Oleh karena itu sebaiknya tanaman yang terserang penyakit busuk akar dibersihkan sampai akar-akarnya dan dikeluarkan dari lokasi kebun benih.

\section{UCAPAN TERIMA KASIH}

Penelitian ini dilakukan dengan dana DIPA Balai Besar Penelitian Bioteknologi dan pemuliaan Tanaman Hutan Yogyakarta. Penulis meng- ucapkan terima kasih kepada Tim Akasia atas kerjasamanya dalam penelitian ini dan Tim ACIAR yang sudah banyak membantu dalam pelaksanaan penelitian dan penyediaan referensi dalam penulisan naskah.

\section{DAFTAR PUSTAKA}

Departemen Kehutanan. (2009). Peraturan Pemerintah Republik Indonesia Nomor 60/Menhut-II/ 2009 tentang Pedoman Penilaian Keberhasilan Reklamasi Hutan. Jakarta: Kementerian Kehutanan.

Departemen Kehutanan. (2009). Statistik Kehutanan Indonesia 2008. Departemen Kehutanan. Jakarta.

Fries, N. (1987). Somatic incompatibility and field distribution of the ectomycorrhizal fungus Suillus luteus (Boletaceae). New Phytol., 107, 735-739.

Gandjar, Indrawati, Sjamsuridzal, W., dan Ariyanti, O. (2006). Mikologi Dasar dan Terapan. Jakarta: Yayasan Obor Indonesia.

Glen, M., Neale, L.B., Anthony, A.F., Susan, Q.N., Lee, S.S., Ragil, L., Karen, M.B., Christopher L.B., \& Mohammed, C.L. (2009). Ganoderma and Amauroderma species associated with root-rot disease of $A$. mangium plantation trees in Indonesia and Malaysia. Australasian Plant Pathology, 38, 345-356.

Guler, P. (2008). Somatic incompatibility in Agaricus bitorquis (Quel.) Sacc. African Journal of Biotechnologhy, 7(3), 276-281.

Guler, P., \& Bicer, H. (2014). The Somatic Incompatibility in Trametes versicolor (L.) Lyod.

Henessy, C., \& Daly, A. (2007). Ganoderma Diseases. Darwin: Northern Territory Government, Plant Pathology, Diagnostic Services.

Herliyana, E.N., Darmono, T., \& Hayati, M. (2012). Penyakit akar Ganoderma sp. pada sengon di Jawa Barat dan Jawa Timur. Jurnal Manajemen Hutan Tropika, XVIII (2), 100-109.

Hidayati, N. (2013). Uji resistensi busuk akar. Laporan Hasil Penelitian, Balai Besar Penelitian Bioteknologi dan Penelitian Tanaman Hutan. Badan Litbang Kehutanan. Tidak Dipublikasikan.

Latifah, Z., \& Ho, Y.W. (2005). Morphological characteristics and somatic incompatibility of Ganoderma from Infected Oil Palm from Three Inland Estates. Malaysian Journal of Microbiology, 1(2), 46-52. 
Purwantisari, S., \& Budi, R.H. (2009). Uji antagonis jamur Phytophthora infestans penyebab penyakit busuk daun dan umbi tanaman kentang dengan menggunakan Trichoderma spp. Isolat Lokal. Jurnal Bioma, 11(1), 14.

Puspitasari, D., \& Rimbawanto, A. (2010). Uji somatik inkompatibilitas Ganoderma philippii untuk mengetahui pola penyakit busuk akar pada tanaman A. mangium dalam Jurnal Pemuliaan Tanaman Hutan, 4 (1), 49-58.
Suwandi, Hamidson, H. \& Naito, S. (2004). Distribution of Rigidoporus lignosus genotype in a rubber plantation, as relevead by somatic compatibility. Mycoscience, 45, 72-75.

Worall, J.J. (1997). Somatic incompatibility in Basidiomycetes. Mycologia, 89(1), 24-36.

Worall, J.J. (2010). Summer heat and an epidemic of cytospora canker of Alnus. Canadian Journal of Plant Pathology, 32, 376-386. 